\title{
Odtujevanje kulturne dediščine: primer premeščenih artefaktov iz mest Slovenske Istre
}

\author{
Janja Babelić, mag. umetnostne zgodovine
}

Med drugo svetovno vojno, ko so obalna mesta pripadala Italiji, je bilo zaradi nevarnosti vojne iz omenjenih krajev premeščenih nekaj predmetov kulturne dediščine. Problematika restitucije umetnin je tako na Slovenskem kot drugod že nekaj desetletij pereč problem. Cilj prispevka je strnjeno predstaviti historični pregled po vojni odtujenih artefaktov iz obalnih mest, $\mathrm{z}$ namenom postavitve trdnih temeljev za nadaljne raziskave.

Ključne besede: kulturna dediščina, 2. sv. vojna, Slovenija, Italija, restitucija.

During World War II, when the coastal towns of Slovenia were part of Italy, many of heritage objects and artifacts were taken to safety and relocated because of bombing threats. The problem of restitution of artifacts is still today a burning question in Slovenia and others parts of the world. The scope of this article is to give a condensed historical review on the fate of the relocated artifacts from the coastal towns, because further research must be placed on solid foundations.

Key words: cultural heritage, WWII, Slovenia, Italy, restitution.

M ed drugo svetovno vojno, ko so obalna mesta severne Istre pripadala Italiji, je bilo zaradi nevarnosti vojne od tam premeščenih nekaj predmetov kulturne dediščine. Predmeti so bili odpeljani na varno, vendar se zaradi sprememb meja $v$ teh okrajih niso nikdar vrnili na svojo izvorno lokacijo. Kmalu po drugi svetovni vojni je Jugoslavija ustanovila komisijo za restitucijo artefaktov ${ }^{\mathrm{I}}$. Cilj prispevka je strnjeno predstaviti usodo po vojni odtujenih artefaktov iz obalnih mest, $\mathrm{z}$ namenom, da bi te raziskave bile $\mathrm{v}$ prihodnje nadgrajene. $\check{Z}_{\mathrm{i}}$ vimo $\mathrm{v}$ času, ko je tematika vračanja umetnin zelo prikladna za politične in populistične namene. Zaradi tega je nujna kontekstualizacija in poglobljena analiza podobnih primerov. Uporabljena metodologija je preplet pregleda umetnostnozgodovinskih, zgodovinskih in arhivskih vi-

I Pojem artefakt v tem kontekstu uporabljam kot širšo definicijo, ki zajema sakralno in profano premično kulturno dediščino. rov. Historični pregled v tem članku predstavlja le temelje za nadaljnje raziskave na tem področju, ker je problem odtujenih umetnin izjemno zahteven za raziskavo, saj pokriva različna raziskovalna področja.

Po Ashworthu je ravno pomen, ki ga pripisujemo dediščini, tisti, ki ji določa vrednost (Ashworth in soavtorji 2007, 3). Nacionalna dediščina je del javne kulturne in zgodovinske sfere, je del procesa vlade in vladanja (Mason in Baveystock 2009, 17). Marta Anico (2009, 63) piše, da je dediščina izjemno učinkovito sredstvo za uveljavljanje kontinuitete in stabilnosti, ki omogoča družbam definiranje in sidranje njihove identitete. Kot jasno kažejo sodobne razlage s področja kritičnih dediščinskih študij, artefakti in nesnovni elementi dobijo vrednost dediščine skozi proces dediščinjenja (heritageisation; Harvey 200I), ki ga sooblikujejo diskurzi. Avtorizirani diskurz v dediščini je tisti, katerega no- 
silci so politične elite in strokovnjaki, stremijo pa h konsenzualnem, narodotvornem tolmačenju zgodovine, in torej dediščine; obratno pa subalterni diskurz temelji na vključujočem načelu različnih družbenih (nehegemonskih) skupin in odpira prostor za konfrontacijo različnih razlag (Smith 2006, 4-6). Dediščina je torej vedno bila ideološko osnovana, je simbolični konstrukt pod vplivom zgodovine, politike in družbenih okvirjev, v katerih nastanejo in so interpretirani kulturni pomeni (Anico 2009, 63), s tem pa instrument kulturne moči (Harvey 200I, I5).

Obstoj neke stvari, po Benjaminu (2003, I5I), je zbir vsega, kar ji je od začetka dodala tradicija, od njenega materialnega trajanja vse do zgodovinskega pričevanja. Enkratna vrednost prave umetnine je utemeljena $\mathrm{v}$ ritualu, $\mathrm{v}$ katerem je imela svojo izvirno in prvotno uporabno vrednost (Benjamin 2003, 154). Mnogi artefakti, kot so na primer knjige, kipi, medalje ipd., so v osnovi narejeni kot premični predmeti, drugi artefakti, ki pa so nepremični oziroma namenjeni za $\mathrm{v}$ točno določen prostor, pomen in vrednost dobivajo iz okolice. Če se ta spremeni, izgubijo kontekst in ambient prikrajšajo za svojo prisotnost. Nekatere artefakte so premaknili zaradi spremembe okolice (tempelj v Aswanu), druge zaradi vojne, kraje ali nesreč. Nekateri se lahko vrnejo, drugi so še vedno na tujem. Odstranitev v nekaterih primerih postane življenjskega pomena za njihovo historično reševanje (Lowenthal 2015, 444). Taka odstranjevanja pa imajo posledice: premik spomenikov uniči njihovo pričevanjsko vrednost in povezava $s$ krajem izvora je mnogokrat izbrisana. Veliko relikvij je danes dostopnih $\mathrm{v}$ muzejih ali galerijah in jih v prvotni katedrali ali oddaljenem gradu ne najdemo več. Če umestitev relikvije med štiri stene pomeni lažji dostop do njih, jim to sočasno odvzame časovno zavedanje, ki ga ne more popraviti niti bližina kraju izvora niti najbolj inovativna in dovršena postavitev (Lowenthal 2015, 448). Opravka imamo s spolzkim področjem, saj je dediščina del preteklosti, s katerim se zelo enostavno manipulira.
$\mathrm{V}$ članku predstavljeni historiat nam osvetljuje pomen restitucije umetnin za Slovenijo in Italijo, poleg tega pa razkriva še mnogo nerešenih vprašanj, predvsem pa političnih ozadij, ki niso bila še ustrezno obravnavana. Primer kliče po kontekstualizaciji predvsem dejstva, da so nekatere rane iz polpretekle zgodovine še odprte. Pomen restitucije umetnin se ne nanaša samo na umetnostno zgodovino, ki ima nalogo raziskati avtorstvo in provenienco odtujenih umetnin, ampak tudi na zgodovinski, družbeni ter politični kontekst, saj je dediščina učinkovito orodje za politično manipulacijo in apropriacijo (tako kulturno kot ozemeljsko). Od sprejetja ICOMOS-ove Beneške listine (1964) dalje (Doktrina I Mednarodne listine ICOMOS 2003, 26), se dediščina varuje $\mathrm{v}$ kontekstu. Vprašanje, ki si ga moramo ob tem postaviti, pa je: Kaj se zgodi v primeru, ko je kontekst sporen? Komu pripada ta dediščina? Dediščinske študije ta problem jasno artikulirajo:

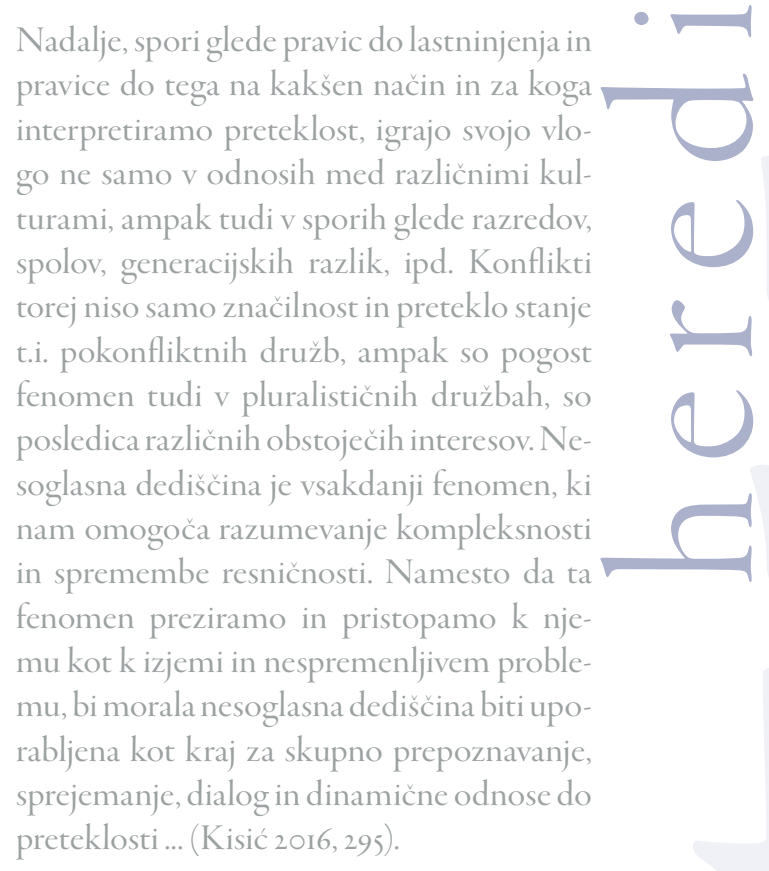

Socialni konstrukti preteklosti so ključni elementi v procesu dominacije, podrejanja in odpora (Silverman 20II, 3). Niso samo ljudje tisti, ki želijo vrnitev in/ali nadzor nad svojo dediščino, tudi države si to želijo in zanimati nas mora, 
zakaj in kako so ti objekti dediščine manipulirani skozi diskurz (Silverman 20II, I4). Ko ljudje definirajo idejo vključevanja in izključevanja, se sklicujejo na povezanost $\mathrm{s}$ krajem oziroma vsaj z reprezentacijo kraja, to pa uporabijo za legitimacijo svojih zahtev po teritoriju (Ashworth in soavtorji 2007,5$)$. Dediščina je sestavljena iz različnih preteklih dogodkov, osebnosti, spominov, mitologij, fizičnih relikvij in krajev, s katerimi je simbolično povezana (Ashworth in soavtorji 2007,40 ). Dediščina je tudi politični proces, $v$ katerem so določeni kraji vključeni v dogovorjen nacionalni pogled na svet, medtem ko so drugi zanikani ali namensko prezrti, ker predstavljajo grožnjo dogovorjeni nacionalni podobi (Knapp in Antoniadou 1998, 33). Današnje razumevanje identitete kot mnogovrstnost lastnin, in potrebe posameznikov do pripadnosti teritorialno določeni družbeni skupini, ni nič manj pomembna kot takrat, ko so se definirale nacionalne države i9. stoletja. Razlika je le v tem, da so identifikacije $\mathrm{z}$ reprezentacijo prostora in kraja postale kompleksnejše, ker globalizacijo spremlja reteritorializacija, ki privilegira regionalno in lokalno na račun nacionalnega (Ashworth in soavtorji 2007, I). Preučevanje dediščine se ne nanaša neposredno na preučevanje preteklosti, ampak na vsebino, interpretacijo in reprezentacijo dediščinskih diskurzov ter na to, kako so izbrani glede na povpraševanje sedanjosti. Pomen je tisti, ki daje vrednost dediščini (Ashworth in soavtorji 2007, 3). Dediščina je socialni konstrukt, ki ga oblikujejo politični, ekonomski in družbeni vplivi sedanjosti. Dediščinski konflikt je postal globalni problem, ker je tako prepleten s procesom družbenega vključevanja in izključevanja, da definira družbene karakteristike z vedno bolj kompleksnimi formami kulturne drugačnosti (Ashworth in soavtorji 2007, 4).

\section{Zgodovinski okvir}

Zgodovinski okvir obravnavanega primera je izredno kompleksen in vreden posebne obravnave, zato sem se odločila, da se osredotočim izključno na nekaj najpomembnejših zgodovinskih prelomnic (za več glej Pirjevec 2007), na katerih slo- ni razlaga v nadaljevanju. Obalna mesta so bila od svojega osnovanja vezana na romanski svet ob severnem Jadranu (med I3. in I8. st. primarno na takratno oblastno strukturo Beneške republike iz. Serenissime), obenem pa v stalnem stiku s slovanskim svetu v mestnem zaledju. Avstrijska oblast v i9. stoletju je večkulturnost še spodbujala. A prav večkulturni značaj regije se je z oblikovanjem nacionalnih držav izkazal za odlično odskočno desko za utemeljevanje ozemeljskih apetitov. Prvo svetovno vojno je dokončno zaključila Rapalska pogodba, podpisana leta 1920 , ki je na novo zarisala mejo med kraljevinama (Italija in SHS) in današnja pokrajina Primorske je pripadla Italiji (Pirjevec 2008, 107-I09). Obdobje med obema vojnama je zaznamoval fašizem in strmoglavljenje slovensko-italijanskih odnosov med prebivalstvom. Po nastopu druge svetovne vojne je v začetku aprila i94I Italija s pomočjo Nemčije in Madžarske napadla Kraljevino Jugoslavijo (Gombač 1996, 8I). Koncu druge svetovne vojne (1945) je sledilo dolgotrajno določanje novih državnih meja. Devetega junija I945 sta generala Arso Milovanović in William D. Morgan podpisala $\mathrm{v}$ Beogradu sporazum, ki je bil povsem v sozvočju zahtevami takratnega ameriškega predsednika Trumana. Jugoslovanske enote naj bi se umaknile iz Trsta, Gorice in drugih območij zahodnega dela Julijske krajine, za t.i. Morganovo črto (Pirjevec 2007, 315). Dvanajstega junija 1945 so se morale jugoslovanske enote, $\mathrm{v}$ skladu s sporazumom iz Beograda, umakniti za demarkacijsko linijo. Obsežno obmejno sporno ozemlje Julijske krajine je bilo razdeljeno na dve okupacijski coni, A in B, od katerih je v pričakovanju dokončne razmejitve na mirovni konferenci prva prišla pod anglo-ameriško, druga pod jugoslovansko vojaško upravo. (Pirjevec 2007, 3I8). Na Pariški konferenci leta 1947 je bila usoda večine spornega ozemlja dorečena, ostalo pa je odprto vprašanje pripadnosti Trsta in njegovega neposrednega zaledja, od Devina do Novigrada. Oblikovana je bila začasna tamponska državica Svobodno tržaško ozemlje (STO) oz. Territorio Libero di Trieste (TLT), ki je imela lasten statut, po katerem je bila država tudi uradno večjezič- 
na. Tudi ta politična tvorba je bila razdeljena $\mathrm{v}$ dve coni in ločeni upravi: cono A, ki je obsegala Trst z okoliškimi vasmi na kraškem robu, je upravljala $Z_{V U^{2}}$; cono $\mathrm{B}$, ki jo obsegala območje od Ankarana do Novigrada, pa je upravljala VUJA ${ }^{3}$ (Poročilo SIZKK 2000, I3; Pirjevec 2007, 368, 374). Po večletnih pogajanjih in skorajšnjem ponovnem spopadu (1953) je bilo tržaško vprašanje razrešeno, posledično pa določena meja med Italijo in Jugoslavijo (in torej med demokratično-kapitalističnim Zahodom ter socialističnim Vzhodom). Z Londonskim sporazumom (oktobra 1954) je cona A pripadla Italiji, cona B pa Jugoslaviji (Pirjevec 2007, 478).

\section{Usoda umetnin iz Kopra, Izole in Pirana pred, med in po vojni}

O usodi artefaktov iz Kopra, Izole in Pirana pred, med in po vojni pišeta zlasti dve avtorici: Sonja Ana Hoyer in Irene Spada. Obe se sklicujeta predvsem na dnevnik honorarnega inšpektorja in direktorja evakuacije umetnin in zaščite umetniškega patrimonija Vidma z okolico, Carla Someda de Marca, ter ostale dosegljive arhivske vire. Zaradi tega se v nadaljevanju sklicujem predvsem nanju, saj sta edini, ki se ukvarjata specifično z odtujenimi artefakti na območju obalnih mest s širšo okolico.

\section{Pred drugo svetovno vojno}

Že po prvi svetovni vojni je italijansko ministrstvo za javno izobraževanje vpeljalo merila za reševanje in ohranjanje umetniške dediščine v primeru oboroženega spopada. Pomembna osebnost, zadolžena za varovanje dediščine, je bil nadzornik Ferdinando Forlati, arhitekt na Nadzorništvu v Benetkah (Spada 2017, 19I). V pismu, poslanem 7. januarja I93I na Direzione generale antichità e belle arti, je takratni nadzornik v Trstu Forlati spisal po njegovem mnenju uporabne nasvete za varovanje nacionalnega umetniškega zakladja pred letalskimi napadi. Predlagal je dve možnosti: direktno obrambo in prenos umetnin na varne kraje. $\mathrm{V}$ pismu je omenjal, da mu

\footnotetext{
Zavezniška vojaška uprava
}

Vojaška uprava Jugoslovanske armade je največ skrbi povzročalo dejstvo, da se je večina umetnin $\mathrm{v}$ njegovi pristojnosti nahajala $\mathrm{v} \mathrm{ob}-$ mejnih okrajih (Spada 2017, 192). Februarja 1932 je ponovno poslal pismo, $v$ katerem je spraševal o napredku glede očuvanja kulturne dediščine pred letalskimi napadi. Takrat je Forlati pripravljal seznam umetnin degni di particolare interesse (posebnega zanimanja) (Forlati 1932 v Spada 2017,193$)$ in seznam pomembnejših stavb. $\mathrm{Na}$ prvi verziji poslanega seznama ni bilo zabeležene Istre (Spada 2017, 193). Italijanski kralj Vittorio Emanuele III je 5. marca I934 odobril prvi dekret za zaščito teritorija in civilnega prebivalstva pred letalskimi napadi Regolamento per la protezione antiaerea del territorio nazionale e della popolazione civile (Uredba za očuvanje pred letalskimi napadi nacionalnega teritorija in civilnega prebivalstva), ki je vseboval odlok o ustanovitvi instituta občinskih in provincialnih odborov za obrambo pred letalskimi napadi (Spada 2017, 195). Ministrstvo za vojno se je odločilo, da brez njihove odobritve nadzorniki niso imeli prostih rok glede ukrepov za očuvanje dediščine (Spada 2017, 196). Januarja 1935 so bili narejeni seznami, vključno z oceno stroškov v primeru premikanja in zaščite umetnin. Forlati ${ }^{4}$ ni verjel, da so obmejni kraji varni za zbiranje umetnin in je bil mnenja, da bi umetnine morali premestiti v Veneto (Spada 2017, 198). Prvi predlog varne lokacije, ki ga je ponudil nadzornik Gino Fogolari, je bil frančiškanski samostan Carceri, sedem kilometrov oddaljen od kraja Este. Zanj se niso odločili, saj je bila stavba v statično slabem stanju (Spada 2017, 199). Predlagane so bile tudi druge lokacije, ki pa se niso uveljavile. Prvi seznam, ki ga je sestavila Regia Soprintendenza alle opere d'antichità e d'arte di Trieste (Nadzorništvo za starine in umetnine iz Trsta), je prišel na Direzione generale antichità e belle arti 21. marca 1935 (Spada 2017, 200). Na seznamu so bile premičnine razdeljene po provincah. Poleg tega so bile na seznamu tudi manjše stvari, za katere so menili, da bi se jih dalo zlahka odtujiti. V primerjavi s se-

4 Konec leta 1935 so Forlatija premestili v Benetke, v Trstu pa ga je nasledil Giovanni Brusin, vendar samo do konca leta 1936, ko ga je zamenjal Bruno Molajoli. Bruna Molajolija je v Trstu kasneje zamenjal Fausto Franco (Spada 2017, 210). 
znami za očuvanje iz prve svetovne vojne so bile na tokratnih seznamih tudi umetnine iz zasebnih rok. Ministrstvo za nacionalno izobraževanje je po Ministrstvu za vojno obvestilo Nadzorništvo, da mora v primeru vojne ohraniti sedež v Trstu (Spada 2017, 20I). Januarja 1936 je Brusin poslal na Direzione generale provizorični seznam umetnin v zasebni lasti, saj naj v danem trenutku ne bi bilo mogoče narediti dokončnega (Spada 2017, 202). Na dopolnjenem seznamu, poslanem februarja 1936, je navedel Koper in Pulo kot kraja, kjer bi se umetnine lahko zbirale (Spada 2017, 202). Koper in Pula sta bila zapisana kot zbirna centra, kjer naj bi se umetnine dokončno zapakiralo in od tam odpeljalo na varno na naknadno določeno lokacijo. V Bolletino d'arte, ki ga je izdalo Ministrstvo za nacionalno izobraževanje aprila 1938, je minister za nacionalno izobraževanje Giuseppe Bottai jasno izrazil svoj namen, $\mathrm{da}$ bo zaščitil umetnine $\mathrm{v}$ sklopu nacionalnega teritorija, hkrati pa je odločno zavrgel idejo profesorja Alberta Geouffreja De La Pradelle, ki je predlagal, da se umetnine premestijo na ozemlje nevtralnih držav (Spada 2017, 209). Premik v nevtralne države po njegovem mnenju ne bi jamčil večje varnosti, ravno obratno. Bal se je, da jih v primeru, če bi Italija vojno izgubila, ne bi nikdar več dobili nazaj (Spada 2017, 210).

\section{Med drugo svetovno vojno}

Italija je stopila v vojno ıo. julija I940. Poudariti je treba, da umetnine iz Kopra, Izole in Pirana niso bile nikdar odpeljane kot vojni plen niti jih niso premestili takratni prebivalci, temveč sta njihov umik z obmejnega področja zaradi zavarovanja pred vojnim uničenjem narekovala italijanska zakona I089 (I. junij 1939) in I04I (6. julij 1940) Protezione delle cose d'interesse artistico, storico, bibliografico e culturale della Nazione in caso di guerra (Hoyer 2005, 15; Spada 2017, 211). Med letoma 1939 in 1940 je bilo veliko število umetnin odpeljanih na varno, posebno iz Istre, saj so te kraje zaradi dogodkov iz prejšnje vojne dojemali kot izredno rizične (Casadio in Castellani 2005, 29). Za vso potrebno logistiko za umik del je poskrbela pristojna spomeniškovarstvena služba, t. i. Nadzorništvo v Trstu (Hoyer 2005, I5). Zbiranje in odvoz umetnin so izpeljali v dveh tednih junija 1940. Ta dogodek je vodil tržaški spomeniškovarstveni nadzornik Fausto Franco. Umetnine so shranili v vili zadnjega beneškega doža Manina v Furlaniji. Dela so zapakirali v zaboje, priskrbelo jih je podjetje za prevoze Exner iz Trsta, ki je skupaj s podjetjem Roiatti iz Vidma izpeljala logistiko prevoza (Spada 2017, 212; Hoyer 2005, I5). Prvotna lokacija, ki je bila predvidena, je bila Rocca Bernarda v Gorici, ker pa je bila poleg smodnišnica, so se raje odločili za Vilo Manin, ki jo je dal v uporabo grof Leonardo (Magani 2005, 33; Spada 2017, 212).

$\mathrm{Na}$ seznamih Nadzorništva, poslanih na Ministrstvo, so našteti sodelavci, ki so sodelovali pri evakuaciji. Na teh seznamih je tudi Koper, kjer so sodelovali Antonio Pozzar, odgovoren za občinsko dediščino, pater Pasquale Giorgio Salico, odgovoren za samostan sv. Ane, in monsinjor Sirotti, odgovoren za stolnico. V Piranu je bil odgovoren Mario Bartoli za občino, pater Lino Biasi za sv. Frančiška in monsinjor Egidio Malusà za cerkve sv. Jurija, sv. Marije in sv. Štefana (Spada 2017, 213). V Vili Manin je bilo shranjenih 380 zabojev z umetninami s celotnega območja Julijske krajine in Furlanije. Vsak zaboj je bil inventariziran s svojo številko; vsaka slika je imela svoj uradni dokument, podpis, pečat in datum; vsak dokument (ki je potrjeval umik del zaradi zaščite pred letalskim bombardiranjem) je bil izdan v treh izvodih: enega je prejel lastnik, enega Nadzorništvo v Trstu in enega izbrani prevoznik umetnin Exner iz Trsta. Najbolj natančen opis umetnin in podatke o zabojih najdemo $\mathrm{v}$ dnevniku honorarnega inšpektorja in direktorja evakuacije umetnin in zaščite umetniškega patrimonija Vidma z okolico, Carla Someda de Marca, ki je dnevnik vodil med ıo. aprilom 1940 in 21. majem 1945 (Spada 2017, 21I, Hoyer 2005, I5). Prva pošiljka umetnin iz Istre je prišla 20. junija $1940 \mathrm{z}$ vlakom. V dnevniku je zabeleženo, da so prejeli naslednje zaboje iz Kopra in Pirana: sedem iz koprskega muzeja, enega iz stolne cerkve Marijinega vnebovzetja v Kopru, štiri iz samostana sv. Ane v Kopru, enega iz cerkve Ma- 
rije Tolažnice v Piranu, enega iz cerkve sv. Štefana v Piranu, štiri iz piranske Občinske palače, pet iz cerkve sv. Jurija v Piranu (Spada 2017, 214).

Petindvajsetega junija 1940 je prispel še en zaboj iz sv. Ane, tako da jih je bilo skupaj pet (Spada 2017, 214). Sonja Ana Hoyer navaja tudi zaboj iz cerkve sv. Frančiška v Piranu, ki pa ga Irene Spada ne omenja (Hoyer 2005, 16, Spada 2017, 214). Someda je v dnevniku zapisal, da ga je zelo skrbela bližina Jugoslavije (Spada 2017, 213). Franco je v istem mesecu razposlal okrožnico $s$ prošnjo za inšpektorje in direktorje muzejev in ostale, ki so se ukvarjali z evakuacijo, da se k zabojem priloži negative $\mathrm{z}$ dokumentiranimi deli in zapisom, ki pojasnjuje vsebino zabojev (Spada 2017, 214). V Vili Manin je začelo zmanjkovati prostora in Someda je moral prositi grofa Manina za dodatne prostore (Spada 2017, 218). Z napredovanjem vojne so se odločili, da zaboje premaknejo v notranjost dežele, dlje od nevarnih vzhodnih meja Italije. To se je izkazalo za zelo težko nalogo, saj so bili premiki zaradi vojnega stanja s prevoznimi sredstvi zelo omejeni (Spada 2017, 219). Že leta 1942 je Someda izrazil zaskrbljenost, saj Ministrstvo ni odobrilo povečanja števila oboroženih stražarjev (Spada 2017, 22I). Leto kasneje v dnevniku navaja, da se je Francu zdelo vedno bolj nevarno imeti umetniška dela v enem samem kraju. Tudi sam Someda je razmišljal o tem, da bi dela razpršili (Spada 2017, 22I). Zaradi nevarnosti in strahu pred tem, da bodo odšli tudi vojaki, sta najela civilno stražo osmih oseb (Spada 2017, 222). Someda je poslal okrožnico lastnikom umetnin, v kateri je pisalo, da obstaja nevarnost poškodb in kraje. Pojasnil je, da imajo, če želijo svojo zasebno lastnino nazaj, na izbiro dve možnosti: lahko pridejo ponjo na lastne stroške ali jo še naprej prepustijo $v$ očuvanje njim, $s$ tem da $\mathrm{v}$ primeru poškodb zanje niso odgovorni. Vsi lastniki niso prišli po umetnine, zato so del zabojev iz Pule in del iz Pirana zaradi onemogočene vrnitve na kraj izvora preselili v videmski muzej (Spada 2017, 222). Nato je jeseni 1943 prišlo do Nemške okupacije Italije. Ustanovljeno je bilo območje OZAK (Operationszone Adriatisches Küstenland / Operacijska cona Jadran- sko Primorje). Odgovoren za umetnine je bil dr. Walter Frodl, direktor celovškega muzeja, ki je nemudoma začel sodelovanje s Somedo. Novembra 1943 se je Nadzorništvo odločilo, da razpusti center v Passarianu in da dela preselijo v San Daniele del Friuli (Spada 2017, 225; Hoyer 2005, 15). Soglasja z nemške strani niso dobili in tudi podjetje Roiatti, ki je pomagalo pri prvi selitvi, se je zaradi strahu, da bi jim zaplenili vozila, odreklo sodelovanju (Spada 2017, 225). Novembra jim je umetnine uspelo preseliti na skrito lokacijo $\mathrm{v}$ San Daniele (Spada 2017, 226). Tiste, ki so jih vrnili na izvorna mesta, pa so doživljale raznoliko usodo. Carpaccieva slika Marija $z$ otrokom in svetniki iz cerkve sv. Frančiška v Piranu, na primer, ni bila vrnjena minoritom v Piran, temveč umeščena na sedež redovne province $\mathrm{v}$ Padovo. Podobno naj bi se zgodilo s poliptihom Cime da Conegliana Marija zotrokom in svetniki, ki je bil leta 1943 sicer vrnjen v Koper, vendar ga je leta 1946 neidentificirani menih odnesel $v$ samostan S. Francesco della Vigna v Benetkah, od tam pa naj bi bil leta 1966 premeščen v Mantovo (Hoyer 2005, 16). Dela niso bila nikdar vrnjena na izvorna mesta, delno tudi zaradi nastanka nove meje med Italijo in Slovenijo, uveljavljene z Mirovno pogodbo z Italijo leta 1947 in Londonskim memorandumom leta 1954 (Hoyer 2005, 17).

\section{Primersv. Ane}

Artefakti iz sv. Ane so doživljali drugačno usodo. Poudariti velja, da je bil lastnik umetnin frančiškanski red in ne država, kot npr. pri umetninah, odpeljanih iz koprskega muzeja. Zaradi tega so se umetnine tudi po kapitulaciji Italije še vedno premikale iz države v državo, saj je bil frančiškanski red prisoten tako na področju Jugoslavije kot tudi v Italiji. Najbolj odmeven je primer poliptiha Cime da Conegliana, ki se je nahajal v samostanu sv. Ane. Leta 1940 so ga odpeljali na varno v Vilo Manin. Nazaj v sv. Ano naj bi prišel 5. novembra 1943 (Algeri in L'Occaso 2005,88 , Hoyer 2005,16 ), vendar obstaja sum, da je poliptih Cime da Conegliana že leta 1942 ali 1943 prišel v Trst, kamor so se v samostan Santa Maria Maggiore zatekli frančiškani (Alge- 
ri in L'Occaso 2005, 88, Spada 2017, 228). Kasneje, leta 1946 ali 1947 , naj bi ga skupaj z okvirjem italijanski patri odnesli v San Francesco della Vigna v Benetke (Algeri in L'Occaso 2005, 88, Hoyer 2005, 16). Ostalim umetninam iz sv. Ane naj bi se pridružil šele leta 1965 , ko so vse artefakte preselili v Mantovo (Algeri in L'Occaso 2005, 88). Umetniška dela so najverjetneje premikali v okviru današnjih meja Italije šele, ko se je vojna bližala koncu. Dela danes hranijo v beneški provinci ordinariata frančiškanov in se trenutno nahajajo v Gemoni (Spada 2017, 229). Irene Spada $\mathrm{v}$ knjigi navaja pismo poslano marca 1944, v katerem so frančiškani iz sv. Ane prosili Nadzorništvo za dobrodelni prispevek 20.000 lir, ki bi pokril del stroškov, porabljenih za izgradnjo zaklonišča pred letalskimi napadi, kamor so spravili umetnine. Da bi Fausta Franca prepričali, kako varno je njihovo zaklonišče, so mu poslali seznam vseh hranjenih umetnin, da bi s tem poudarili njihovo vrednost:

I. Ancona di Cima da Conegliano: deset slik z okvirji Vittoria da Feltre (šest zabojev),

2. Oltarna podoba $V$ imenu Jezusa: Benedetto Carpaccio, en zaboj,

3. oltarna podoba Snemanje križa: Girolamo di Santa Croce, en zaboj,

4. slika Križanje in svetniki: Palma il Giovane, en zaboj,

5. slika Madona na prestolu in Sante del Catena, en zaboj,

6. slika Sveti Bernardin iz Siene: Sano di Pietro, en zaboj,

7. dve sliki sv. Joahim in sv. Ana: Girolamo da Santa Croce, en zaboj,

8. manjša dela (Spada 2017, 227).

Bibliografski material:

I. pet vesperalov iz is. stoletja,

2. sedem gradualov iz I5. stoletja,

3. dva latinska kodeksa T. Livii Historiae in Sermones,

4. dva grška kodeksa Isocrates ad Daemonicum in Lexicon Graecum,
5. 5 I inkunabul (Spada 2017, 227).

\section{Drugo povojno obdobje (I945-I954)}

Jugoslovanski Prosvetni odsek okrožnega narodnoosvobodilnega odbora za Tržaško okrožje (NOO) je že I5. maja 1945 okrajnim referentom odredil popis škode na dediščini. Ker je bil od leta 1947 Koper pod okriljem cone B STO, je zanje veljal odlok št. 22., ki ga je 29. maja 1945 izdal Primorski narodnoosvobodilni odbor (PNOO) za slovensko Primorje in Trst (Rogoznica 2015, 243). Odlok je bil izdan v obdobju jugoslovanske vojaške prisotnosti v Trstu. Podobno kot odlok št. I9 o zaščiti knjižnic, arhivov in kulturnih spomenikov, ki ga je januarja 1945 objavilo Predsedstvo Slovenskega narodnoosvobodilnega boja (SNOS), je tudi odlok PNOO postavljal pod zaščito naravoslovne, umetniške in druge predmete kulturne in zgodovinske vrednosti $\mathrm{v}$ privatni in javni lasti. Določal je, da morajo navedeni predmeti biti ohranjeni na mestu, kjer so izvorno stali. Uničevanje, poškodovanje, premeščanje, prodaja in druge oblike odtujevanja so bile prepovedane $s$ kazenskim pregonom. Odlok PNOO za razliko od odloka SNOS ni zagotavljal institucionalne spomeniške zaščite, saj ni navajal konkretnih organov, ki bi bili odgovorni za nadzor in zaščito spomenikov, niti ni opredeljeval pogojev njihovega upravljanja. V Pariški mirovni pogodbi z Italijo (1947) je pisalo, da mora Italija vrniti Jugoslaviji premoženje in arhivsko gradivo, ki je bilo odneseno z območja, okupiranega leta 194I (Žitko 2005, 3I). Odlok je do leta 1953 predstavljal edini pravni predpis, ki je urejal spomeniško varstvo in zaščito kulturnih spomenikov na območju cone B STO (Rogoznica 2015, 244). Za izdelavo seznamov odnesenih ali uničenih predmetov kulturne dediščine iz koprskega območja je bil odgovoren okrajni referent za prosveto. Tako je oktobra 1945 Karlo Prijon, referent pri OLO (Okrajni ljudski odbor) Koper, sestavil splošni seznam rokopisov in knjig koprske mestne knjižnice, ki so bili odneseni v Benetke. Na seznamu je kot manjkajoče gradivo navajal: knjige koprske komune, zgodovinske spise srednjega veka, občinske akte, doku- 
mente občinske uprave, rokopise, pergamente in razne dokumente, med njimi zakonik iz is. stoletja in originalne statute Kopra, rokopise družine Carli, akte iz obdobja francoske oblasti v Kopru, akte iz obdobja prve avstrijske oblasti v Kopru, dokumente in pisma iz obdobja italijanskega risorgimenta (preporod naroda) in drugo. Vrednost odnesenega je bila izredno velika. Prijon je že istega leta predlagal zahtevek po restituciji odpeljanega gradiva (Rogoznica 2015, 245).

$\mathrm{V}$ začetku petdesetih let je bilo zaradi nove politične ureditve vprašanje spomeniškega varstva potisnjeno v ozadje oziroma podrejeno političnim vprašanjem. Kmalu po zaključku vojne so bili v vsaki republiki tedanje Jugoslavije organizirani okrožni zbirni centri (ZC) za kulturnozgodovinske predmete (Rogoznica 2015, 246). V Sloveniji so bili centri v Mariboru, Celju, Novem mestu, osrednji federalni zbirni center pa se je nahajal v Ljubljani. Vojaška uprava jugoslovanske armade (VUJA) je kot najvišji oblastni organ za področje cone B STO v vprašanja spomeniškega varstva intervenirala le v redkih konkretnih primerih na osnovi zahtev jugoslovanske oblasti ali mednarodnih pritiskov, zadolžitev za reševanje varstvenih in spomeniških vprašanj pa je bila dana odseku za prosveto, delujočem pri IOLO (Istrski Okrajni ljudski odbor) (Rogoznica 2015, 247). Potem, ko je novembra 1949 po službeni dolžnosti koprski okraj obiskal konservator Zavoda za zaščito in znanstveno proučevanje kulturnih spomenikov in prirodnih znamenitosti Slovenije Ciril Velepič, je republiški zavod od sveta za prosveto in kulturo IOLO zahteval čimprejšnjo organizacijo in vzpostavitev službe za spomeniško varstvo ter pregled in inventarizacijo kulturnih spomenikov koprskega okraja (Rogoznica 2015, 249., Žitko 2005, 31). Nemudoma je ugotovil, da je bilo odnesenih veliko predmetov (Žitko 2005, 3I).

V okviru okrožnega sveta za prosveto in kulturo sta bila leta 1950 oblikovana dva odbora: odbor za šolstvo in odbor za znanost in kulturo. V okviru slednjega je bila ustanovljena posebna komisija za pregled kulturnih spomenikov, katere člani so bili: Roman Savnik, Jurij Jan in Srečko
Vilhar. Komisija je opravljala preglede knjižnic, arhivov in ostalih zgodovinskih spomenikov $\mathrm{v}$ coni B STO. Večkrat je tudi intervenirala in izdala nekatere odloke $\mathrm{z}$ namenom zaščite knjižnega in arhivskega gradiva ter drugih kulturnih spomenikov (Rogoznica 2015, 249). Ko je bilo zaradi zaostritve političnih razmer maja 1952 ukinjeno Istrsko okrožje (IOLO) in so bile njegove pristojnosti prenesene na OLO Koper in Buje, se je na območju cone B STO začela širiti jugoslovanska zakonodaja (Rogoznica 2015, 25I). Ob začetku leta 1953 je bil na področju okraja Koper uveden Zakon o varstvu kulturnih spomenikov in prirodnih znamenitosti LRS iz leta 1948 (Rogoznica 2015, 25I; Žitko 2005, 3I). V prvi polovici istega leta je bila v Kopru ustanovljena komisija za pregled knjig in umetnin, ki jo je vodil Miroslav Pahor. Do leta 1954 sta v njej sodelovala tudi Srečko Vilhar in Emil Smole (Rogoznica 2015, 25I).

\section{Obdobje po prikljucitvi cone B Jugoslaviji (I954-I9gI)}

\section{Restitucija v širšem kontekstu}

Problematika restitucije umetnin je tako na Slovenskem kot drugod že nekaj desetletij pereč problem. Že od poznega i8. stoletja so velike imperialne velesile pričele zbirati antikvitete z osvojenih teritorijev: partenonski okras, asirski levi in reliefi iz Korsabada, H amurabijev zakonik, skulpture iz mavzoleja iz Halikarnasa, ipd. (Renfrew 2000, I8). Med najbolj odmevnimi sta tudi kamen iz Rozete, ki se je po vojni med Francozi in Britanci znašel v Britanskem muzeju (Ikram 20II, I45), ter busta Nefretete v berlinskem Egipčanskem muzeju. (Ikram 20II, I47). Omenjeni primeri so javnosti najbolj poznani, a predstavljajo le manjšino nerešenih primerov restitucije artefaktov. Navedeni primeri nimajo veliko skupnega s primerom v pričujočem prispevku. Če pa se osredotočimo na čas in geografski kontekst, primerljivo usodo kot pri odtujenih umetninah iz obalnih mest, odkrijemo v usodi zadarskega zaklada, o katerem piše Antonija Mlikota. Primer je seveda zanimiv, saj časovno in regionalno sovpada s primerom odtuje- 
nih umetnin iz Istre, vendar je potek dogodkov po vojni v tem primeru nekoliko drugačen. Njena raziskava temelji na arhivu Robertsove komisije, ki je pod okriljem ameriške vojske uradno delovala med leti 194I in 1946 (Mlikota 2012, 24I). Uradni naziv komisije je bil Comission for the Protection and Salvage of Artistic and Historic Monuments in Europe (Mlikota 2012, 242), dobila pa je ime na prvem sestanku ki ga je vodil sodnik vrhovnega sodišča Owen J. Roberts, po katerem je skupina dobila ime. Komisija se je povezala $\mathrm{z}$ lokalnim prebivalstvom in poznavalci, ter že na začetku vojne izdelala baze podatkov o umetniških spomenikih v nevarnosti. Izdelali so približno 700 zemljevidov, na katerih so bili označeni objekti kulturnega in historičnega pomena, ki bi utegnili biti ogroženi. Priročniki, izdelani za vsako državo posebej, so imeli poleg zemljevidov tudi sezname pomembnejših del kulturne dediščine (Mlikota 20I2, 246). Tako Zadar kot tudi Koper, Izola in Piran so na seznamih beleženi kot mesta italijanske države. Ti seznami naj bi predstavljali nekakšno prvo pomoč za prepoznavanje in zaščito na terenu. Primarna funkcija komisije (njene člane so običajni vojaki imenovali Monuments Man) je bila svetovanje ameriški vojski pri načrtovanju vojnega delovanja tako, da bi se kar se da dobro zaščitile kulturne dobrine (Mlikota 20I2, 247). Vojno osebje in člani MFAA so morali na terenu prepoznati in zaščititi kulturne spomenike in evidentirati ter vračati ukradeno, sekundarna naloga pa je bila poiskati način za vračilo ukradenega (Mlikota 20I2, 247). Dokumentarno gradivo pokriva tudi področje bivše Jugoslavije (Mlikota 20I2, 249). Edine informacije, ki jih je imela MFAA o umetninah iz Zadra, so prišle od dr. Mercurellija, nekdanjega asistenta za antikvitete in profesorja Luigija Creme (Mlikota 20I2, 255). Luigi Crema nosi velike zasluge za rešitev zadrskih umetnin, saj je namestil zaboje z ogroženimi umetninami v zvonik sv. Marije (Mlikota 20ı2, 256). Njegov asistent dr. Mercurelli, ki je zadnji ostal v Zadru, je obljubil, da bo MFAA poslal podrobno poročilo o umetninah, ki so bile odtujene, vendar je nepričakovano preminil (Mlikota 2012, 259). Po njegovi smrti je profesor Galli iz Ancone napisal poročilo o šestih zabojih iz Zadra, ki so prispeli $\mathrm{k}$ njim in bili pred tem zakopani pod kripto sv. Cirijaka (Mlikota 20I2, 260). V poročilu decembra I 944 piše, da je bilo teh šest zabojev del večjega tovora (I zabojev) iz Zadra in da so najverjetneje ostali zaboji v Benetkah. Zaboji so vsebovali različne najdbe iz dveh liburnijskih grobov iz Nina, najdbe rimskih grobov iz Zadra, beneške in grške kovance, rimski nakit in rimske geme, slike in razpela (Mlikota 2012, 260). V poročilu Fausta Franca o prenosu zabojev $\mathrm{z}$ umetninami iz Zadra v Benetke piše o I 4 zabojih, ki so prišli iz cerkve sv. Donata v Trst (Mlikota 20I2, 26I). Zaboje so iz Trsta preselili v doževo palačo v Benetke ı. julija 1944 (Mlikota 20ı2, 265). Sočasno so premestili tudi I 49 zabojev arhivskih dokumentov iz Zadra v Benetke. Operacija Zara, ki jo je vodila MFAA se je začela 28 . avgusta 1945 zjutraj $\mathrm{v}$ prostorih doževe palače $\mathrm{v}$ Benetkah (Mlikota 20I2, 267). Operacija Zara je vojaški dokument, ki razlaga okoliščine dogodkov in opisuje stanje predmetov kulturne dediščine iz Zadra. Komisija je posnela in katalogizirala celoten inventar iz šestih zabojev, ki so bili zakopani pod kripto. Opaziti je bilo, da je v škatli za bilo šest kosov namesto navedenih 75 iz prvotnega seznama iz leta 1940 (Mlikota 2012, 269). Vsak predmet so popisali in inventarizirali, če ga niso prepoznali, pa so ga podrobno opisali. Zaboje so spet zapečatili 9. septembra 1945. Namenjeni so bili nazaj v Zadar, vendar tja niso nikdar prispeli (Mlikota 2012, 270). Jugoslovanski minister za izobraževanje je v Istro leta 1947 poslal konservatorja Ljuba Karamana, da bi zbral vso dokumentacijo o predmetih kulturne dediščine, ki so bili prepeljani v Italijo. V njegovem priročniku piše, da so bili predmeti kulturne dediščine prepeljani v Benetke, kar je potrjevalo zgodbo nekdanjih zaposlenih v zadrskih kulturnih institucijah (Mlikota 20I2, 27I). Stirinajst zabojev je bilo aprila 1944 odpeljanih iz Zadra. Šest zabojev, zakopanih pod kripto, je imelo priložen originalen seznam iz leta 1940, ostalih osem hranjenih pod stopniščem sv. Donata pa ne, vendar so naredili novega pri popisovanju v operaciji Zara (Mlikota 20I2, 


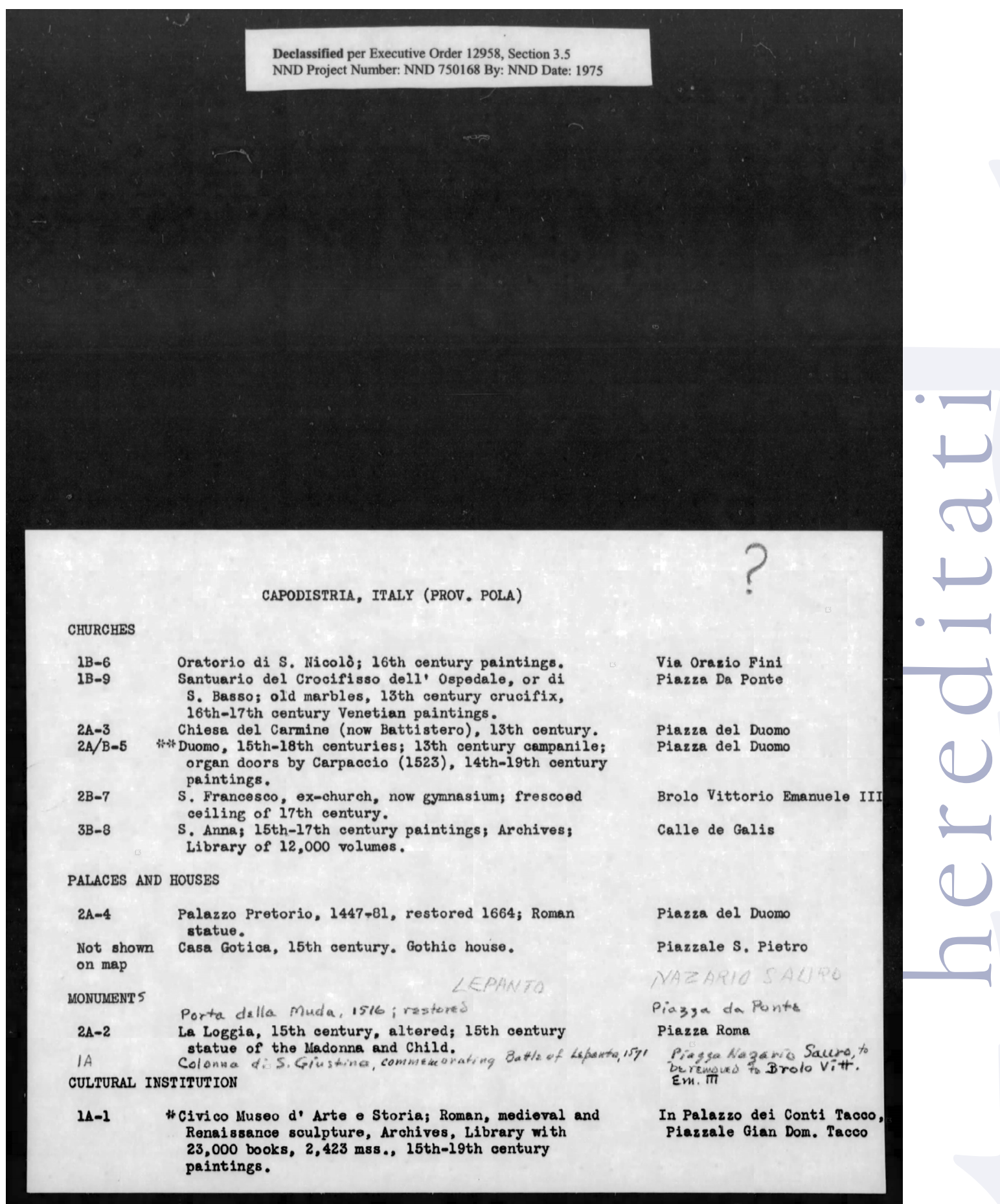

Priloga I: Seznam pomembnih umetnin in lokacij, ki jih je treba zaščititi v primeru spopada. MFAA, Roberts Commission, Maps Showing Areas to Be Spared Destruction During World War II, Europe: Hungary - Italy. Vir: https:// www.fold3.com/image/114/301220105 
275). Mnogo let so trdili, da je bil material iz Zadra odpeljan leta 1943, medtem ko dokumentacija MFAA dokazuje, da je bil odpeljan aprila 1944 po kapitulaciji Italije (Mlikota 20I2, 276).

\section{Vprašanje restitucije umetnin iz Istre v času socialisticne Jugoslavije}

Z Londonskim sporazumom leta 1954 je severni del Istre (brez Milj) postal del Jugoslavije. Zahteve po vrnitvi umetnin so se tokrat okrepile. Vlada FLRJ je takoj po Londonskem memorandumu že marca 1955 poslala italijanski vladi noto, v kateri je zahtevala vrnitev kulturne dediščine iz nekdanje cone B STO. Italijanska stran na noto ni odgovorila in je $\mathrm{v}$ nadaljnjih pogajanjih zavračala vse zahteve po vrnitvi, saj naj bi bilo po njihovem mnenju vprašanje razdelitve STO še vedno odprto (Žitko 2005, 31). Po podpisu Londonskega memoranduma 5. oktobra 1954 so $\mathrm{z}$ ureditvijo tržaškega vprašanja nastale nove razmere. Jugoslovanska stran je pričakovala, da se bo odprla možnost za vrnitev arhivov, umetnin in kulturnih predmetov, odnesenih iz cone B STO. Jugoslovanska ambasada v Rimu je leta I955 še pred koncem poganjanj v Gorici skušala doseči, da bi razširili delovno področje goriške komisije še na razdelitev arhivov v Trstu, italijanska stran pa se ni strinjala. Želeli so podrobne sezname jugoslovanskih zahtev, da bi jih preučili in v Trstu opravili priprave. V naslednjih letih je jugoslovanska stran poskušala doseči, da bi vprašanje kulturnih restitucij in delitev arhivov uredili v okviru Trsta med generalnim konzulatom FLRJ in generalnim komisariatom v Trstu (Oblak Čarni 2008, 288). Pristojne službe so seznam odnesenih umetnin skrbno pripravljale od leta I955 in ga vse do danes poglabljale in dopolnjevale (Hoyer 2005, 19).

Posebno vlogo je odigrala tudi Cerkev, katere vlogo pri vračanju je treba še raziskati. Takoj po prevzemu koprskega samostana sv. Ane so ljubljanski frančiškani sprožili postopek za vrnitev samostanskih liturgičnih predmetov, ki so jih leta 1947 italijanski redovniki odnesli iz Kopra. V zvezi s tem je bila ena glavnih dilem, ali se lahko predmeti vrnejo brez jugoslovanskih ca- rinskih postopkov in plačila carine. Izkazalo se je, da carine niso bili oproščeni. Ko naj bi slike iz Benetk, namenjene v samostan sv. Ane v Kopru, prispele na koprsko carino, niso smele preko meje, ker carina ni bila poravnana. $\mathrm{V}$ korespondenci med spomeniškim zavodom in jugoslovansko carino je spomeniški zavod pojasnjeval carini, da se za vrnitev odnesenih umetnin ne plačuje carina, a se zvezni jugoslovanski carinski urad za to ni zmenil. Posledično so se vsi predmeti vrnili v Benetke (Hoyer 2005, I8).

Po nenehnih intervencijah jugoslovanske vlade je italijansko zunanje ministrstvo konec leta 1959 privolilo na nadaljevanje pogajanj o restituciji umetniških in zgodovinskih dobrin. Delegaciji obeh strani sta se sestali I8. januarja 1960 v Milanu (Oblak Čarni 2008, 288). Jugoslovansko delegacijo je vodil svetnik Miloš Morača, italijansko pa pooblaščeni minister De Novalis. Na pogovorih so vsaj glede nekaterih vprašanj skoraj dosegli soglasje, vendar so bila pogajanja na željo italijanske strani prekinjena. Ko so se 27. aprila ponovno sestali v Rimu, je italijanska stran, ki jo je takrat vodil pooblaščeni minister Rodolfo Siviero, zastopala stališče, da italijanska delegacija, ki se je pogajala v Milanu, ni imela pooblastil za sklepanje sporazumov. Italijanska delegacija je predlagala odlog do junija. Ob snidenju meseca junija 1960 je vodja italijanske delegacije predlagal ponovno preložitev, dokler ne bi posamezna ministrstva predložila italijanski vladi poročila o predmetih, ki jih je zahtevala Jugoslavija (Oblak Čarni 2008, 288). Jugoslovanska delegacija je odlaganju nasprotovala, saj je menila, da so bile zahteve znane že dolgo in da so imeli italijanski organi dovolj časa, da bi jih preučili. Po ostrem protestu zunanjega ministrstva Jugoslavije so se pogajanja nadaljevala na politični ravni, brez sodelovanja izvedencev. V prostorih jugoslovanskega zunanjega ministrstva v Beogradu so med 6. in II. avgustom 1960 nadaljevali pogovore. Beograjski zapisnik so podpisali I. novembra, v njem so določili, da se morajo pogajanja čim prej končati. Predlagali so sporazum, s katerim bi dokončno uredili problematiko restitucije (Oblak Čarni 2008, 288). Popolnoma nereše- 
$467 / 55$.

BLENCO DEGLI ARREDI SACRI DA RITORNARE AL U.R.P. PROVINCIALE DI LUBIANA PBR LA CHIBSA DI S. AMNA IN CAPODISTRIA CUI APPARTENEVANO.

\section{1.- INo 3 (tre) calic1. Due in argento finemente lavorati. Uno con} la sola coppa d'argento.

2.- No 1 (una) pisside d'argento.

3.- No 1 (una) porta reliquie (piede di ottone dorato e porta reliquie d'argento).

Oltre alla biancheria già segnalata nel precedente elenco:

4.- $\mathbb{N}^{\circ} 22$ (ventidue) fra tovaglie e sopratovaglie.

5.- No 12 (dodici) camici. - sofice

6.- No 6 (sei) amiti.

7.- № 13 (tredici) corporali.

8.- $\mathbb{N}^{\circ} 15$ (quindici) pale.

9.- No 16 (sedici) purificatoi.

10.- No 16 (sedici) manutergii.
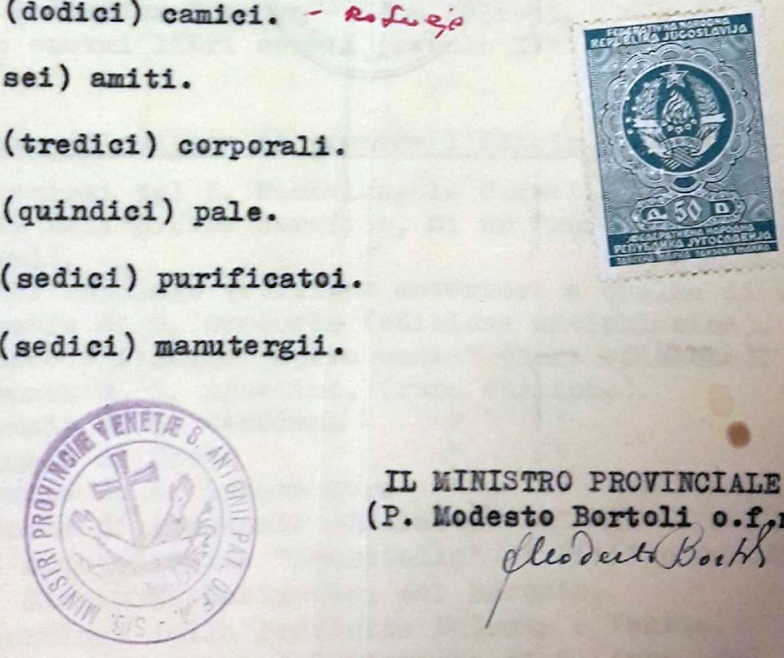

II UINISTRO PROVINCIALE

(P. Hodesto Bortoli 0.1,m.)

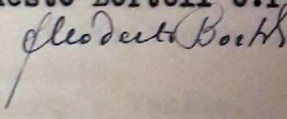

M.R.P. BENIANINO TOUSIC O.F.X.

Franciskanski samostan

Presernov trg 4

(Jugoslavia)

IJUBLJAITA

Priloga 2: Seznam odpeljanih liturgičnih predmetov. Vir: Arhiv Samostana sv. Ane v Kopru, foto: Janja Babelić 
no je ostalo vprašanje vračila arhivov in drugih kulturnih dobrin iz nekdanje cone B STO. V posebni prilogi beograjskemu zapisniku so zapisali, da je jugoslovanska stran med pogovori ponovila zahtevo po restituciji, saj so bili mnenja, da Londonski memorandum temelji na mirovni pogodbi in Italijo posledično obvezuje k vrnitvi umetnin, vendar naj italijanska delegacija ne bi imela navodil za razpravljanje o gradivu iz cone B STO (Oblak Čarni 2008, 289).

Vprašanje restitucije so ponovno odprli leta 196I v jugoslovansko-italijanskem Sporazumu o reguliranju restitucije kulturnih dobrin Jugoslaviji, ki je bil ratificiran 6. marca 1962 (Oblak Čarni 2008, 289, Žitko 2005, 3I). Pomembna je bila tudi Dunajska konvencija o pravu mednarodnih pogodb iz leta 1969, ki sta jo ratificirali obe državi. Pomembna je bila zaradi pisne korespondence med zunanjima ministroma SFRJ Milošem Minićem in Republike Italije Marianom Rumorjem o kulturni dediščini, s katero sta se jugoslovanski in italijanski minister dogovorila, da se bosta pol leta po uveljavitvi Osimskega sporazuma (1975) italijanska in jugoslovanska delegacija sestali in poskušali rešiti odprta vprašanja (Žitko 2005, 3I). Osimske sporazume, mednarodne pravne akte, sta Io. novembra 1975 podpisali Republika Italija in SFRJ, v mestu Osimo, z njimi pa so urejali vprašanje meja med državama. Na podlagi zgoraj omenjene korespondence med Minićem in Rumorjem, je bila ustanovljena jugoslovansko-italijanska komisija, ki je zasedala aprila 1978 v Rimu, decembra 1979 v Portorožu in 198I ponovno v Rimu. Jugoslovansko delegacijo je vodil Stjepan Gumel, direktor Zavoda za spomeniško varstvo SR Hrvaške, italijansko pa na prvem zasedanju veleposlanik Giovanni Falchi, na drugem in tretjem pa Mario Profili. Na prvem zasedanju je jugoslovanska delegacija predložila in obrazložila knjigo zahtev s 529 postavkami. Šlo je predvsem za gradivo nekdanje cone B STO. Leta 1979 je Mario Profili ostro napadel jugoslovansko delegacijo, saj je menil, da so zahteve pretirane in presegajo določila Osimskega sporazuma (Oblak Čarni 2008, 292). Italijanska stran je zavračala vsakršno raz- pravljanje o zahtevah po vrnitvi kulturnih dobrih $\mathrm{z}$ ozemlja, priključenega $\mathrm{z}$ mirovno pogodbo leta 1954. Pripravljeni so bili sprejeti le nekaj zahtev in še te izključno v svežnju, kar je pomenilo, da bi jugoslovanska stran morala sprejeti italijansko ponudbo v celoti ali od nje odstopiti. Italijanska delegacija je na tem srečanju uradno priznala, da korespondence Minić - Rumor ni ratificirala (Oblak Čarni 2008, 292). Jugoslovanska delegacija je imela pooblastila Cerkve oziroma verskih ustanov, da se dogovarja za restitucijo njihove kulturne dediščine (Žitko 2005, 32). Leta 198I je italijanska stran ponovila stara merila za dogovor, po katerih jugoslovanska stran ne bi imela pravice zahtevati materiala ne iz Istre ne iz Dalmacije. Italijanska komisija ravno tako ni želela razpravljati o gradivu, odnesenem pred letom 1940 in po letu 1945. Poleg tega bi jugoslovanska stran morala dokazati, kje točno v Italiji se posamezni predmeti nahajajo. Na tej točki so bila pogajanja blokirana. Sprejeli so skupni zapisnik, v katerem sta obe strani ugotovili razhajanja v razlagi korespondence Minić - Rumor in sporazuma iz leta 196I ter sklenili o tem obvestiti svoji vladi (Oblak Čarni 2008, 293). Leta 1987 je prišlo na Brionih do predsedniškega sestanka, na katerem so se dogovorili za nov datum sestanka komisij, do katerega pa ni prišlo (Oblak Čarni 2008, 293).

\section{Po osamosvojitvi Slovenije (I9gI)}

Slovenija je postala pravna naslednica Jugoslavije v Osimskih sporazumih z notifikacijo z dne 29. julija 1992 (Uradni list RS 1992). S tem je restitucijska komisija nadaljevala delo jugoslovanske delegacije, dodeljene za restitucijo umetnin. Še pred tem je jeseni I99I Slovenija pripravila revidiran seznam samo s slovenskimi terjatvami, ki je bil izročen italijanski strani (Oblak Čarni 2008, 293). Po osamosvojitvi Slovenije so se prizadevanja nadaljevala in Italija je $\mathrm{z}$ izmenjavo not potrdila pripravljenost za oblikovanje mešane slovensko-italijanske komisije, ki naj bi obravnavala nerešena vprašanja (Žitko 2005, 34). Kljub temu se $\mathrm{v}$ devetdesetih letih na področju odtujenih 
umetnin ni veliko dogajalo, najverjetneje zaradi vstopnih pogajanj Slovenije v Evropsko unijo.

Največji preboj se je zgodil, ko so italijanske oblasti is. maja 2002 sklicale tiskovno konferenco, na kateri je italijanski državni podsekretar na Ministrstvu za dediščino in kulturne dejavnosti Vittorio Sgarbi predstavil razloge, ki naj bi botrovali odprtju ir zabojev z umetninami iz obalnih mest, zaprtih od leta 1940. Uradni razlog naj bi bil nujnost restavriranja in konserviranja umetniških del. Glede na zgodovinske okoliščine pa lahko sklepamo, da so odprtje zabojev povzročili tudi drugi še neraziskani razlogi, ki so najbrž povezani s tem, da je Sgarbi mesec kasneje zaključil svoj mandat (podatki dostopni na spletni strani italijanske vlade - glej vire). Odprtje zabojev je odprlo pandorino skrinjico o restituciji umetniških del iz Kopra, Izole in Pirana (Hoyer 2005, I4). Posledično je prišlo tudi do restavriranja nekaterih umetnin in do njihove predstavitve na razstavi Histria: opere d'arte restaurate, ki je potekala v tržaškem muzeju Revoltella med 23. junijem 2005 in 6. januarjem 2006. Leta 2005 je izšel tudi obsežen katalog razstave, ki je vseboval številne strokovne prispevke, med drugim izpod peresa Vittoria Sgarbija, Francesce Castellani, Fabrizia Maganija, Stefanie Mason in drugih.

Omeniti je potrebno, da je junija 2004 potekal tridnevni mednarodni simpozij na Univerzi na Primorskem Istra in Jadran v zgodnjem nover veku: umetnostni dialog med obalo in celino, ki ga je vodil dr. Stanko Kokole. Kot je povedal dr. Kokole v intervjuju za Primorske novice, so na simpoziju predstavili za I5. in I6. stoletje najpomembnejša dela slovenske Istre, med katerimi so slike znanih mojstrov, kot so Vittore Carpaccio, Cima da Conegliano, Alvise Vivarini in Giovanni Bellini. Tuji poznavalci so bili slabo seznanjeni s problematiko odtujenih umetnin (Figelj 2004, 16). Kot navaja novinarka Klavdija Figelj, je italijanska stran zavrnila predlog Slovenije za zasnovo skupne komisije, ki naj bi poskrbela, da se dela vrnejo na stara mesta (Figelj 2004, 16).
$\mathrm{V}$ tem času je prišlo tudi do pomembnega premika: izr. prof. dr. Sonja Ana Hoyer je odkrila nahajališča večine še pogrešanih umetnin iz samostana sv. Ane. Rezultat odkritja je bil izid temeljne monografije, ki obravnava problematiko odtujevanja umetnin s področja današnje Slovenije, V Italiji zadržane umetnine iz Kopra, Izole, Pirana. Pomen monografije je predvsem v tem, da je prva publikacija, ki se dotika omenjene problematike in omenja nekatera nahajališča odtujenih artefaktov. Slednji so bili tako prvič predstavljeni slovenski javnosti, s čimer je monografija tudi oživila javno razpravo o tej tematiki. Od leta 2005 dalje ni bilo konkretnejših premikov pri vračanju umetnin. De iure slovensko-italijanska restitucijska komisija še vedno obstaja, de facto pa je precej mirujoča.

Uradno stališče italijanske strani je kompleksno, vendar lahko povemo, da italijanska stran ni naklonjena vračanju iz istrskih obalnih mest odtujenih umetnin. Kot piše Vittorio Sgarbi v katalogu Histria: opere d'arte restaurate: da Paolo Veneziano a Tiepolo: [Trieste, Civico Museo Revoltella 23 giugno 2005 - 6 gennaio 2006], ki je nastal ob razstavi z umetninami iz omenjenih zabojev, si nihče ni upal dotakniti teh umetnin, saj so se bali diplomatskega in političnega vprašanja, ki bi ga odprle (Sgarbi 2005, 40). Vittorio Sgarbi trdi, da obstajata dva možna pogleda na situacijo odtujenih umetnin: na eni strani princip, po katerem naj bi umetnine pripadale fizičnemu in geografskemu kontekstu, iz katerega izhajajo, druga možnost pa je princip, po katerem naj bi umetnine pripadale zgodovinskemu in kulturnemu kontekstu, ki jih je ustvarila, pri katerem teritorij predstavlja samo geografsko in fizično dimenzijo. $V$ večini primerov se ti dve možnosti prekrivata, kar pa po Sgarbijevem mnenju ne velja za Istro (Sgarbi 2005, 40). Sgarbi namreč trdi, da je historični ambient, v katerem so umetnine nastale, kulturno pripada italijanskemu kontekstu, in da umetnine posledično ne sodijo več na teritorij, od koder so izhajale, saj je le-ta povsem spremenjen, slovaniziran in politično razdeljen med Slovenijo in Hrvaško (Sgarbi $2005,4 \mathrm{I}$ ). 


\section{Zaključek}

Historiat vprašanja restitucije istrskih umetnine dokazuje izrazito kompleksnost problema. Dogodki iz prve in druge svetovne vojne so pripeljali do današnjega statusa quo glede vračila umetnin. Predmeti so bili po drugi svetovni vojni odpeljani na varno, vendar se zaradi sprememb meja v teh okrajih niso nikdar vrnili na svojo izvorno lokacijo. Kljub ustanovitvi komisije za restitucijo po vojni in poskusov dogovarjanja z Italijo se do konca devetdesetih letih na področju odtujenih umetnin ni veliko dogajalo. Kljub številnim naporom slovenske politike in stroke, se je največji premik zgodil, ko so italijanske oblasti leta 2002 sklicale tiskovno konferenco na to temo, kar je oživilo problem restitucije umetniških del iz Kopra, Izole in Pirana. Kulturna dediščina se je izkazala kot politični resurs, s katerim se zelo enostavno manipulira. Zaradi tega, mora biti poudarek na procesu vedno novega ustvarjanja kultur $\mathrm{v}$ sedanjosti in ne na preprostem obračanju k tradiciji kot izgovoru za ohranjanje družbenih, ekonomskih in političnih neenakosti (Harrison 2013, 230). Po Harrisonu bi morali dojemati ohranjanje različnosti, ne kot proces reševanja ali ohranjanja ogroženih relikvij iz preteklosti, ampak kot aktiven in kreativen proces iskanja temeljev za skupno človečnost $\mathrm{v}$ vseh oblikah, ki so nam dostopne v sedanjosti (Harrison 20I3, 164), s čimer se potrjuje sodobna teorija o prepoznavanju novih, celostnih diskurzov dediščine (inclusive heritage discourse; Kisić 2016).

Dediščina je več kot samo zapuščina, je proizvod sedanjosti, ki si ga lastijo različne družbene skupine kot instrument za ustvarjanje novih identitet in njenih referentov. Dediščina je ideološki konstrukt, ki izhaja iz kompleksnih političnih, zgodovinskih in družbenih dinamik, $s$ katerimi se določene strukture in reference izbirajo, kombinirajo in interpretirajo, da bi pridobili nove pomene in identitetne simbole (Anico 2009, 67). Dediščina je torej politični proces in kot taka a priori vsebuje moč politične izbire idej, vrednotenja in znanja, ki jih razstavi javnosti preko dediščinskih diskurzov in naracij (Ani- co 2009, 67). Ravno zaradi tega so dediščina in muzeji močna sredstva za posredovanje idej in vrednot v procesih ustvarjanja pomena. Predstavljajo kulturno ideologijo in so v vseh pogledih (zavedno ali nezavedno) politični. Muzeji in dediščina imajo ta dar, da lahko ustvarjajo nove identitete, vrednote in razumevanja ter promovirajo kulturna doživetja, ki omogočajo gledalcem, da gradijo lastne pomene in interpretacije. To pa ni preprosta naloga, saj so muzeji mnogokrat del širše politične debate in igrajo pomembno družbeno vlogo $\mathrm{v}$ naštetih procesih (Anico 2009, 68). Pomembno je vedeti, da premikanje ostalin in pomnikov lahko življenjsko vpliva na nacionalno in kulturno identiteto (Lowenthal 2015, 447). Prav to težo in kompleksnost pa nosi vprašanje odtujenih umetnin iz obalnih mest.

\section{Povzetek}

Problematika restitucije umetnin je izredno kompleksen problem, saj je kulturna dediščina del preteklosti s katero se lahko zelo enostavno manipulira. Vsak primer odtujevanja si je med seboj različen. Nekaj primerov premeščanja artefaktov je odmevnejših, usoda večine odtujenih umetnin pa je javnosti nepoznana. Med manj poznanimi je tudi prmer Zadarskega zaklada, ki je bil med drugo svetovno vojno, podobno kot umetnine iz Kopra, Izole in Pirana, premeščen na ozemlje današnje Italije. Zaradi dogodkov iz prve svetovne vojne so te kraje dojemali kot potencialno nevarne za hranjenje artefaktov. Med odpeljanimi umetninami iz Istre, je posebno zanimiv primer frančiškanskega samostana sv. Ane, saj je bil lastnik umetnin frančiškanski red in ne država, kot npr. pri artefaktih, odpeljanih iz koprskega muzeja. Zaradi tega so se umetnine tudi po kapitulaciji Italije še vedno premikale iz države v državo, saj je bil frančiškanski red prisoten tako na področju Jugoslavije kot $\mathrm{v}$ Italiji. V Mirovni pogodbi sklenjeni z Italijo (1947) je pisalo, da mora Italija vrniti Jugoslaviji premoženje in arhivsko gradivo, ki je bilo odneseno z območja, okupiranega leta 1941. Z Londonskim memorandumom (1954) je slovenska Istra pripadla Jugoslaviji in zahteve po vrnitvi umetnin so se tokrat okrepile. Vlada FLRJ je takoj po Londonskem memorandumu že marca 1955 poslala italijanski vladi noto, $v$ kateri je zahtevala vrnitev kulturne dediščine iz nekdanje cone B STO. Kljub ustanovitvi 
komisije za restitucijo in poskusov dogovarjanja z Italijo se do konca devetdesetih letih na področju odtujenih umetnin ni veliko dogajalo. Največji premik se je zgodil, ko so italijanske oblasti I5. maja 2002 sklicale tiskovno konferenco, na kateri se je italijanski državni podsekretar na Ministrstvu za dediščino in kulturne dejavnosti Vittorio Sgarbi predstavil vsebino I zabojev odpeljanih iz Istre leta 1940. To je oživilo problem restitucije umetniških del iz mest Slovenske Istre, ki še danes ostaja odprt.

\section{Summary}

The issue of restitution of artworks is an extremely complex problem, since cultural heritage is part of the past that can be easily manipulated. Case of alienation differ strongly among each other. Some examples of relocated artefacts are prominent, while the fate of most relocated artworks remains unknown to the public. Such is the case of the relocated artefacts from the northern Istrian town during WWII and the consequent dispute over their appurtenance. Due to the historic events of World War I, the Slovenian territories that today border with Italy, were perceived during World War II by the then Italian authorities as potentially dangerous for storing artistic artefacts. Among the items taken from Istria, the most interesting is the Franciscan monastery of St. Anna / Sv. Ana in Koper/Capodistria since the owner of the artworks was the order itself and not the State as was the case for the Municipality museum in the town. As a result, the artworks from one country to the other even after the end of WWII, since the order was present both in Italy and Yugoslavia. The Peace treaty of Paris (1947) stated that Italy should return to Yugoslavia all the artefacts and archival material that has been relocated from the occupied areas by 194I. With the London Memorandum (1954), the contested area of Northern Istria became part of Yugoslavia, so the claims of restitution were revived. A first note with the claim of restitution was sent by the Yugoslav government to the Italian one already in 1955. Despite the establishing of a Restitution Commission and various attempts to negotiate with Italy, no further developments occurred until late 1990s. A main shift took place when the Italian authorities convened a press conference on May 15, 2002 at which the deputy minister for Culture, Vittorio Sgarbi, presented the content of II boxed that were relocated from Istria in 1940. The issue remains open until present, while it raises a fundamental theoretical question regarding the conservation of artefacts on their original locations in contested areas that underwent a major change in population.

\section{Viri in literatura}

Anico, M. 2009. "Representing identities at local municipal museums: Cultural forums or identitiy bunkers?" V: Heritage and Identity, Engagement and Demission in the contemporary World, urednici: Marta Anico in Elsa Peralta, 63-75. New York. Ashworth, G. J., Graham B., Tunbridge J. E. • 2007. Pluralising pasts: Heritage, Identity and Place in Multicultural Societies, London.

Algeri G. in L'Occaso S. 2005. "Le opere d'arte della chiesa di San't Anna di Capodistria." $\mathrm{V}$ : Histria: opere d'arte restaurate: da Paolo Veneziano a Tiepolo: [Trieste, Civico Museo Revoltella 23 giugno 2005 - 6 gennaio 2006], 87-96. Milano: Electa.

Benjamin, W. 2003. Umetnina v času, ko jo je mogoče tehnično reproducirati. Izbrani spisi. Ljubljana: Studia humanitatis.

Casadio, P., in Castellani F. 2005. "Per introdurre." V: Histria: opere d'arte restaurate: da Paolo Veneziano a Tiepolo: [Trieste, Civico Museo Revoltella 23 giugno 2005 - 6 gennaio 2006], 29-30. Milano: Electa.

Čebron Lipovec, N. 2015. "'I'm Telling the Story of the Town": Places in a Contested Space." V: At Home but Foreigners. Population transfers in 2oth Century Istria. Uredniki: Katja Hrobat Virloget, Catherine Gousseff, Gustavo Corni, I89207. Koper: University of Primorska, Science and Research Centre, Annales University Press.

Figelj, K. 2004. "O renesansi v Istri lahko govorimo”: dr. Stanko Kokole o I5. in 16. stoletju. Primorske novice, 58, št. 5I (24. jun. 2004), 16. 
Gombač, B. 1996. Slovenija, Italija; od preziranja do priznanja. Ljubljana, Debora.

Harrison, R. 2013. Heritage: Critical approaches. Oxford: Routledge.

Harvey, D. C. 200I. "Heritage pasts and heritage presents: Temporality, meaning and the scope of heritage studies." International Journal of Heritage Studies, Vol. 7 , No. 4.

Hoyer, S. A. 2005. "V Italiji ostale umetnine iz Kopra, Izole in Pirana.” V: V Italiji zadržane umetnine iz Kopra, Izole, Pirana, I4-2I, 36-43, 58-66. Piran/Pirano: Zavod za varstvo kulturne dediščine Slovenije, Območna enota/ Instituto per la tutela dei beni culturali della Slovenia, Unità territoriale/ Institute for the Protection of Cultural Heritage of Slovenia, Regional Office; Ljubljana: Ministrstvo za kulturo Republike Slovenije/ Ministero per la cultura della Repubblica di Slovenia/ Ministry of Culture of the Republic of Slovenia.

Ikram, S. 20I I. "Collecting and Repatriating Egypt's Past: Towards a New Nationalism." V: Contested Cultural Heritage, Religion, Nationalism, Erasure, and Exlusion in a Global World, urednica: Helaine Silverman, I4I-I54. New York: Springer.

International Council of Monuments and Sites. 2003. Doktrina / Doctrine, Mednarodne listine ICOMOS / ICOMOS International Charters I. Uredil Jovo Grobošek. Ljubljana: Združenje za ohranjanje spomenikov in spomeniških območij ICOMOS.

Kisić, V. 20I6. Governing heritage dissonance. Amsterdam, European Cultural Foundation.

Knapp, A. B., in Antoniadou, S. 1998. "The cultural heritage of Cyprus." V: Archaeology Under Fire: Nationalism, politics and heritage in the Eastern Mediterranean and Middle East, urednica: Lynn Meskell, 13-43. London.
Lowenthal, D. 2015. The past is a foreign country: revisited. Cambridge: Cambridge University Press.

Magani, F. 2005. 1940-1946. "La

Soprintendenza ai Monumenti e alle

Gallerie della Venezia Giulia e del Friuli e la protezione delle opere d'arte in Istria."

V: Histria: opere d'arte restaurate: da Paolo Veneziano a Tiepolo: [Trieste, Civico Museo Revoltella 23 giugno 2005 - 6 gennaio 2006], 3I-39. Milano: Electa.

Mason, R., in Baveystock, Z. 2009. "What role can digital heritage play in the reimagining of national identities? England and its icons." V: Heritage and Identity, Engagement and Demission in the contemporary World, urednici: Marta Anico in Elsa Peralta, 15-29. New York.

Mlikota, A. 2012. "MFAA - Dosje Zadar, nove spoznaje o umjetninama odnesenima iz zadra u italiju za vrijeme drugog svjetskog rata." Asseria, vol. 10, 2012: 239-210.

Oblak Čarni, M. 2008. "Restitucije arhivov, kulturno umetniških predmetov in bibliotek ter delitev arhivov med Jugoslavijo in Italijo po drugi svetovni vojni." Arhivi 3I, 2008, št. 2.: 279-294.

Pirjevec, J. 2007. "Trst je naš!” - Boj Slovencev za morje (I848-I954). Ljubljana: Nova revija.

Poročilo slovensko-italijanske zgodovinskokulturne komisije (Koper, 25. julij 2000). Zadnji dostop 22. I. 2019. http://www. mzz.gov.si/fileadmin/pageuploads/ Zakonodaja_in_dokumenti/dokumenti/ Porocilo_SIZKK.pdf

Renfrew, C. 2000. Loot, Legitimacy and Ownership. London: Bristol Classical Press.

Rogoznica, D. 2015. “Organizacijske posebnosti in problemi spomeniškega varstva $\mathrm{V}$ koprskem okraju (1945-1962).” V: Začetki spomeniške službe v Istri, urednica: Deborah Rogoznica, 243-280. Koper: Histria editiones.

Silverman, H. 20ir. "Contested Cultural Heritage: A Selective Historiography.” 
V: Contested Cultural Heritage, Religion, Nationalism, Erasure, and Exlusion in a Global World, urednica: Helaine Silverman, I-50. New York.

Sgarbi, V. 2005. "Arte d'Istria, arte degli Istriani." V: Histria: opere d'arte restaurate: da Paolo Veneziano a Tiepolo: [Trieste, Civico Museo Revoltella 23 giugno 2005 - 6 gennaio 2006], 40-46. Milano: Electa.

Smith, L. 2006. Uses of heritage. Routledge. Spada, I. 2017. L'Italia in Istria, Tutela, conservazione e restauro dei beni culturali tra le due guerre mondiali. Venezia: Marsilio.

Uradni list. 1992. Akt o notifikaciji nasledstva sporazumov nekdanje Jugoslavije z Republiko Italijo. Uradni list RS, št. 40/1992, z dne I4. 8. 1992. Zadnji dostop 22. I. 2019. https://www.uradni-list.si/ glasilo-uradni-list-rs/vsebina/1992-020060 ?sop $=1992-02-0060$

Žitko, S. 2005. "Prizadevanja oblasti za vrnitev v Italiji ostale kulturne dediščine.” V: $V$ Italiji zadržane umetnine iz Kopra, Izole, Pirana, 30-35. Piran/Pirano: Zavod za varstvo kulturne dediščine Slovenije, Območna enota/ Instituto per la tutela dei beni culturali della Slovenia, Unità territoriale/ Institute for the Protection of Cultural Heritage of Slovenia, Regional Office; Ljubljana: Ministrstvo za kulturo Republike Slovenije/ Ministero per la cultura della Repubblica di Slovenia/ Ministry of Culture of the Republic of Slovenia.

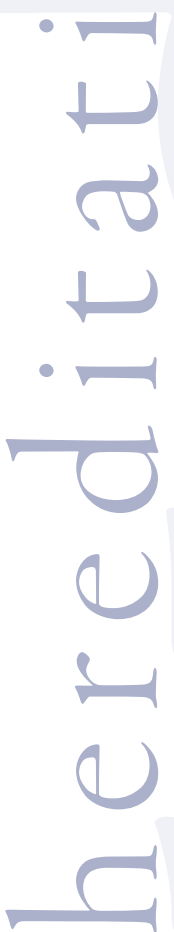

